IZA DP No. 9664

The Acceleration of Immigrant Unhealthy Assimilation

Osea Giuntella

Luca Stella

January 2016

Forschungsinstitut zur Zukunft der Arbeit Institute for the Study of Labor 


\title{
The Acceleration of Immigrant Unhealthy Assimilation
}

\author{
Osea Giuntella \\ University of Oxford \\ and IZA \\ Luca Stella \\ University of Wuppertal \\ and IZA
}

\section{Discussion Paper No. 9664 \\ January 2016}

\author{
IZA \\ P.O. Box 7240 \\ 53072 Bonn \\ Germany \\ Phone: +49-228-3894-0 \\ Fax: +49-228-3894-180 \\ E-mail: iza@iza.org
}

\begin{abstract}
Any opinions expressed here are those of the author(s) and not those of IZA. Research published in this series may include views on policy, but the institute itself takes no institutional policy positions. The IZA research network is committed to the IZA Guiding Principles of Research Integrity.

The Institute for the Study of Labor (IZA) in Bonn is a local and virtual international research center and a place of communication between science, politics and business. IZA is an independent nonprofit organization supported by Deutsche Post Foundation. The center is associated with the University of Bonn and offers a stimulating research environment through its international network, workshops and conferences, data service, project support, research visits and doctoral program. IZA engages in (i) original and internationally competitive research in all fields of labor economics, (ii) development of policy concepts, and (iii) dissemination of research results and concepts to the interested public.
\end{abstract}

IZA Discussion Papers often represent preliminary work and are circulated to encourage discussion. Citation of such a paper should account for its provisional character. A revised version may be available directly from the author. 
IZA Discussion Paper No. 9664

January 2016

\section{ABSTRACT}

\section{The Acceleration of Immigrant Unhealthy Assimilation*}

It is well-known that immigrants tend to be healthier than US natives and that this advantage erodes with time spent in the US. However, we know less about the heterogeneity of these trajectories among arrival cohorts. Recent studies have shown that later arrival cohorts of immigrants have lower entry wages and experience less economic assimilation. In this paper, we investigate whether similar cohort effects can be observed in the weight assimilation of immigrants in the US. Focusing on obesity, we show that more recent immigrant cohorts arrive with higher obesity rates and experience a faster "unhealthy assimilation" in terms of weight gain.

JEL Classification: J15, I10

Keywords: health assimilation, healthy immigrant effect

Corresponding author:

Luca Stella

Schumpeter School of Business and Economics

University of Wuppertal

Rainer-Gruenter-Str. 21

42119 Wuppertal

Germany

E-mail: Stella@wiwi.uni-wuppertal.de

\footnotetext{
* We thank Hendrik Jürges and seminar attendees at the Schumpeter School of Business and Economics for their helpful comments. All errors are our own.
} 


\section{Introduction}

With more than a third of the US adult population reporting a body mass index above 30 , obesity represents a major public health challenge for the US government. The impact of obesity on medical care costs is large (Finkelstein et al., 2009; Cawley and Meyerhoefer, 2012). Obesity has been shown to be importantly associated with the risk of heart disease, stroke, type 2 diabetes and certain types of cancer. Furthermore, obesity has important effects on individual wages and productivity (Cawley, 2004; Cawley et al., 2007).

Despite their lower socio-economic status, first-generation immigrants exhibit lower obesity rates than their native counterparts upon their arrival in the US. However, the immigrants' advantage erodes with time spent in the US (Antecol and Bedard, 2006), and obesity rates are particularly high among Hispanics $(42.5 \%)$. There is extensive literature documenting the healthy immigrant effect for several health outcomes (e.g., self-reported health status, longevity, infant health, and BMI). Previous studies point to immigrant selectivity and socio-cultural protection as the main explanations for immigrants' initial health advantage and its subsequent deterioration (Riosmena et al., 2013; Chiswick, 2008; Antecol and Bedard, 2006; Kennedy et al., 2006; Jasso et al., 2004). However, we still know relatively little about the process of "unhealthy assimilation" and its heterogeneity across different groups and immigrant cohorts.

Economists have long been interested in analyzing the extent of immigrants' economic assimilation (Chiswick, 1978). While early studies based on cross-sectional evidence found evidence of a rapid wage convergence, Borjas $(1985 ; 1995)$ showed that accounting for the presence of cohort fixed effects substantially reduces the rate of economic assimilation because more recent immigrants had relatively lower earnings upon entry than earlier cohorts do. Furthermore, Borjas (2015) showed that there are cohort effects in both wage levels and the rate of wage growth, with more recent cohorts experiencing less economic assimilation.

To the best of our knowledge, no studies have investigated whether the health assimilation of immigrants has changed over time in a manner parallel to that observed for wage assimilation. To fill this gap in the literature, this paper uses data from the public version of the Integrated Health Interview Survey (1989-2014) to analyze cohort differences in obesity levels and in the weight assimilation observed over the time spent in the US.

Similarly to what Borjas (2015) reported for wages, there are cohort effects not only for obesity, with more recent immigrant cohorts having relatively higher rates of obesity upon arrival, but there also exist cohort effects in the rate of obesity assimilation with time spent in the US, with more recent cohorts showing a higher rate of unhealthy weight assimilation compared with earlier cohorts. Immigrants who came to the US in 1990 found their initial obesity advantage narrowed by approximately $50 \%$ during their first 10 years 
in the US. In contrast, immigrants who came after the 2000s have a much faster rate of convergence with native obesity levels, with their advantage shrinking by $71 \%$ after 10 years.

\section{Data}

We draw individual-level data from the Integrated Health Interview Survey (IHIS), a public data repository that integrates the National Health Interview Survey (NHIS) data. A unique feature of this data source lies in its the long running time series; this survey provides data from 1963 to 2014 , thereby allowing researchers to study long-term trends and differences in health status and care.

In this study, we focus on the period from 1989 to 2014 because information about the number of years spent in the US is not collected before 1989. To ensure the representativeness of the sample, we restrict our focus to men and women who are 25-64 years old at the time of the interview, and we exclude those who immigrated to the US before the age of 18 years. ${ }^{1}$ Our dependent variable is an indicator of obesity, conventionally defined as a body mass index (BMI) greater than or equal to 30. Observations with missing data for obesity, years since migration, year of arrival, ${ }^{2}$ years of education, and indicators for currently married and currently employed individuals are excluded. Throughout the analysis, we separately considers four ethnic groups: all ethnic origin groups, Hispanics, whites and blacks. After these restrictions, we obtain a working sample that contains 651,743 US natives (including 42,174 Hispanics, 500,485 whites, and 95,376 blacks) and 78,050 immigrants (including 39,922 Hispanics, 14,984 whites, and 5,928 blacks). ${ }^{3}$

Descriptive statistics by ethnic group on the primary variables of interest for men and women are displayed in Tables 1 and 2, respectively, with the means of the individual characteristics for the US natives listed next to those of the immigrants. For the sample as a whole, the native men and women have better educational outcomes than their immigrant counterparts (approximately 13 years of schooling for natives versus 11.5 years for immigrants); they are less likely to be married (approximately $62 \%$ for natives versus $70 \%$ for immigrants), and native women are significantly more likely to work at the time of the interview (approximately $69 \%$ for the native women versus $55 \%$ for the immigrant women). A particularly striking finding is that native men and women have a greater risk of being obese than their immigrant counterparts

\footnotetext{
${ }^{1}$ Antecol and Bedard (2006) and Borjas (2015) also used similar age intervals.

${ }^{2}$ The immigrant's year of arrival is calculated as the difference between the survey year and the years since migration to the US. The number of years since migration is reported as a categorical variable with five intervals: 0-1, 1-4, 5-9, 10-14 and 15+. To construct a continuous variable for the year of arrival, we linearize the years-since-migration variable using the midpoint value for each interval. Following Borjas (2015), the interval " $15+$ years since arrival" is coded as 29 years.

${ }^{3} \mathrm{As}$ in Antecol and Bedard (2006), the all-origins sample size exceeds the sum of the white, Hispanic, and black samples because it also contains all "other" ethnic origins (e.g., Asians and Indians). However, the small sample size does not allow us to analyze this group separately.
} 
(approximately $21 \%$ for natives versus $16 \%$ for immigrants). Native men also appear to be at a greater risk of being overweight, and native men and women exhibit higher BMIs. It is important to note that a similar pattern is observed for each ethnic group.

\section{[Table 1 - around here]}

\section{[Table 2 - around here]}

\section{Empirical Specification}

As previously stated, the focus of this paper is to investigate the patterns of cohort differences in both the level of immigrant health upon entry to the US and in the rate of growth of immigrant health assimilation. To this end, we employ a simple linear probability model for obesity that expands the framework by Antecol and Bedard (2006) to allow for the presence of cohort differences in the rate of health assimilation. While Antecol and Bedard (2006) assume that the effects of assimilation on health are constant across arrival cohorts, we allow these effects to vary by each entry cohort. Similar to Borjas' (2015) model for wages, our model can be written in the following manner:

$$
Y_{i}=\delta A_{i}+\gamma C_{i}+\theta\left(A_{i} C_{i}\right)+\beta X_{i}+\varepsilon_{i}
$$

where the unit of observation $i$ denotes the individual (immigrant or native) aged 25-64 years at the time of the interview, the outcome $Y_{i}$ is a binary variable for obesity $(B M I \geq 30)$ observed for individual $i, A_{i}$ refers to a linear variable indicating the number of years the immigrant has resided in the US (equal to 0 for natives), and $C_{i}$ represents a vector of fixed effects that capture a specific immigrant-arrival cohort (the omitted category is given by comparable natives). Specifically, the coefficient $\delta$ denotes the effect of assimilation on obesity, while the parameter $\gamma$ indicates whether at the time of arrival in the US, immigrants become more or less likely to be obese relative to otherwise similar natives. A key element of novelty relative to Antecol and Bedard (2006) is that in model (1), we include the factor $A_{i} C_{i}$, i.e., the interaction between the linear term of the years-since-migration variable and each dummy in the vector of cohort fixed effects. This interaction implies that each arrival cohort is allowed to have its own growth path regarding obesity. By taking this approach, we are able to explore the differential assimilation patterns across immigrant- 
arrival cohorts. The variable $X_{i}$ includes the individual's age (introduced as a third-order polynomial) fully interacted with a variable indicating whether the person is foreign- or native-born. Finally, $\varepsilon_{i}$ represents an idiosyncratic error term.

\section{Main Results}

Table 3 presents the results of a simple ordinary least squares (OLS) estimation of the linear probability model for obesity (1), using the pooled data from the entire 1989-2014 period. ${ }^{4}$ Specifically, the upper part of Table 3 contains the full set of immigrant-arrival cohort fixed effects that identify cohort-level differences in obesity between immigrants at the time of entry to the US and comparable natives. The lower part of Table 3 provides the interactions between cohort fixed effects and the variable measuring the number of years since migration. Following Borjas (2015), who examined immigrants' wage assimilation, these interactions indicate the amount of obesity convergence across immigrant cohorts over their first 10 years in the US. ${ }^{5}$

We estimate equation (1), which allows for both level and growth cohort differences by dividing the sample into all ethnic origin groups (see column 1 for the whole sample and columns 2 and 3 for males and females, respectively), Hispanics (see column 4), whites (see column 5), and blacks (see column 6).

When examining the sample as a whole (see column 1), we find that the cohort effects are uniformly, significantly negative and become smaller in absolute value for more recent arrival cohorts. Consistent with the previous literature, these results suggest the presence of the healthy immigrant effect, with more recent cohorts being relatively more obese than earlier cohorts. Focusing on the immigrant cohorts that arrived in the US after 1985 - those we are able to observe at their time of arrival in the US -, we find a reduction of the immigrant advantage of lower incidences of obesity compared with natives. The initial entry obesity level of immigrants who arrived between 1985 and 1990 is 12 percent lower than that of natives, whereas the initial entry obesity level of immigrants who arrived between 2005 and 2014 is 9 percent lower than that of natives. In general, similar patterns are found by gender and ethnic groups. When considering the same immigrant cohorts of Hispanics, by far the largest immigrant ethnic group in the US, the entry obesity advantage declines from 18 percent to 12 percent relative to the native counterparts.

In the lower part of Table 3 , the analysis of the rate of health assimilation by arrival cohort for the entire sample (see column 1) shows that the estimated coefficients for the interactions are positive and significant, and their magnitude tends to increase with more recent arrival cohorts. These results reveal that the rate

\footnotetext{
${ }^{4}$ As shown in Table 4, the average marginal effects obtained using a Probit model remain substantially unchanged.

${ }^{5}$ To construct these interactions, we follow Borjas (2015).
} 
of obesity assimilation started to significantly increase with the immigrants who arrived between 1996 and 2000. Prior to that time, immigrants could expect an increase in their relative obesity of approximately 5 to 6 percentage points during their first decade in the US. However, immigrants who entered after 1995 experienced an increase between 7 and 9 percentage points. Column 4 shows that the trend in the rate of obesity assimilation in the pooled sample is driven by Hispanics, for whom the acceleration is particularly pronounced. ${ }^{6}$

\section{[Table 3 - around here]}

\section{Conclusion}

Several studies have documented that immigrants are healthier than natives upon arrival in the US but that their initial health advantage declines with time spent in the US. These facts are commonly referred to as the healthy immigrant effect or, in the US, as the Hispanic health paradox. Previous studies showed evidence of a healthy immigrant effect with respect to several health outcomes, including BMI and obesity. However, we know less about health assimilation.

Using data from the Integrated Health Interview Survey (1989-2014), we document the long-term trends in immigrant assimilation for obesity rates. Our main finding is that - similar to what Borjas (2015) found for wages -, there are cohort effects not only in the obesity levels of immigrants upon arrival, but also in the rate of obesity assimilation, with recent cohorts exhibiting a substantially faster rate of assimilation for obesity.

Changes in life-style behaviors in the country of origin and changes in the reference group in the US, with the obesity rate increasing among second-generation Hispanics, can partly explain the observed longterm trajectories of weight assimilation. Understanding the reasons for cohorts' differences in health upon arrival and their rate of "unhealthy assimilation" may shed light on the growing obesity rates observed among ethnic minorities in the US. Potential mechanisms behind these patterns include the trends in obesity rate in the country of origin where obesity rates have been dramatically increasing over the last decades (see Popkin et al., 2004; Leung, 2014); peer effects (Ali et al., 2011) together with the increase in the obesity rate of the reference group (e.g., Hispanics); as well as the decline in the rate at which the new immigrants add to their human capital stock and the fact that larger national origin groups experience less economic

\footnotetext{
${ }^{6}$ Including controls for years of schooling, marital status and labor force participation yields substantially identical results. As expected, better-educated, married and working individuals are less likely to be obese. The results are available from the authors upon request.
} 
assimilation (Borjas, 2015). Unfortunately, because of the limitation of the data (e.g., lack of information on the area of residence and country of origin) identifying the specific drivers behind these patterns is beyond the scope of this paper. Future research could investigate these trends and help policy makers shape policy programs aimed at encouraging preventive medicine and promoting the resilience of healthy behaviors among immigrant descendants. 


\section{References}

Ali MM, Amialchuck A, Heiland FW. 2011. Weight-related behavior among adolescents: the role of peer effects. e21179.

Antecol H, Bedard K. 2006. Unhealthy Assimilation: Why do immigrants converge to American Health Status Levels?. Demography 43(2): 337-360.

Borjas GJ. 1985. Assimilation, changes in cohort quality, and the earnings of immigrants. Journal of Labor Economics 463-489.

Borjas GJ. 1995. Assimilation in Cohort Quality Revisited: What Happended to Immigrant Earnings in the 1980s?. Journal of Labor Economics 13(2): 211-245.

Borjas GJ. 2015. The slowdown in the Economic Assimilation of Immigrants: Aging and Cohort Effects Revisited Again. Journal of Human Capital forthcoming.

Cawley J. 2004. The impact of obesity on wages. Journal of Human Resources 39(2): 451-474.

Cawley J, Rizzo JA, Haas K. 2007. Occupation-specific absenteeism costs associated with obesity and morbid obesity. Journal of Occupational and Environment Medicine 49(12): 1317-1324.

Cawley J, Meyerhoefer C. 2012. The medical care costs of obesity: an instrumental variables approach. Journal of Health Economics 31(1): 219-230.

Chiswick BR. 1978. The effect of Americanization on the earnings of foreign-born men. The Journal of Political Economy 897-921.

Chiswick BR, Lee YL, Miller PW. 2008. Immigrant selection systems and immigrant health. Contemporary Economic Policy 26(4): 555-578.

Finkelstein EA, Trogdon JG, Cohen JW, Dietz W. 2009. Annual medical spending attributable to obesity: payer-and-service-specific estimates. Health affairs 28(5): w822-w831.

Jasso G, Massey DS, Rosenzweig MR, Smith JP. 2004. Immigrant health: selectivity and acculturation. Critical perspectives on racial and ethnic differences in health in late life 227-266.

Kennedy S, McDonald JT, Biddle N. 2006. The healthy immigrant effect and immigrant selection: evidence from four countries.

Leung LA. 2014. Healthy and Unhealthy Assimilation: Country of Origin and Smoking Behavior Among Immigrants. Health Economics 23(12): 1411-1429.

Popkin BM, Gordon-Larsen P. 2004. The nutrition transition: worldwide obesity dynamics and their determinants. International Journal of Obesity 28: S2-S9.

Riosmena F, Wong R, Palloni A. 2013. Migration selection, protection, and acculturation in health: a binational perspective on older adults. Demography 50(3): 1039-1064. 


\section{Tables}

Table 1: Summary Statistics for Men, by Nativity and Ethnic Origin

\begin{tabular}{|c|c|c|c|c|c|c|c|c|}
\hline \multirow[b]{2}{*}{ Variable } & \multicolumn{2}{|c|}{ All Origins } & \multicolumn{2}{|c|}{ Hispanic } & \multicolumn{2}{|c|}{ White } & \multicolumn{2}{|c|}{ Black } \\
\hline & Native & Immigrant & Native & Immigrant & Native & Immigrant & Native & Immigrant \\
\hline \multirow[t]{2}{*}{ BMI } & 27.007 & 26.153 & 28.063 & 26.935 & 26.864 & 26.172 & 27.414 & 26.090 \\
\hline & $(4.361)$ & $(3.851)$ & $(4.649)$ & (3.915) & $(4.256)$ & (3.735) & $(4.729)$ & (3.608) \\
\hline \multirow{2}{*}{ Overweight (BMI 25+) } & 0.661 & 0.596 & 0.745 & 0.683 & 0.653 & 0.602 & 0.679 & 0.609 \\
\hline & $(0.473)$ & $(0.491)$ & $(0.436)$ & $(0.465)$ & $(0.476)$ & $(0.489)$ & $(0.467)$ & $(0.488)$ \\
\hline \multirow{2}{*}{ Obese (BMI 30+) } & 0.209 & 0.139 & 0.283 & 0.181 & 0.196 & 0.135 & 0.251 & 0.125 \\
\hline & $(0.406)$ & $(0.346)$ & $(0.451)$ & $(0.385)$ & $(0.397)$ & $(0.341)$ & $(0.433)$ & $(0.330)$ \\
\hline \multirow{2}{*}{ Immigrated in $1960-1970$} & & 0.157 & & 0.141 & & 0.277 & & 0.099 \\
\hline & & $(0.364)$ & & $(0.348)$ & & $(0.447)$ & & $(0.298)$ \\
\hline \multirow{2}{*}{ Immigrated in $1971-1980$} & & 0.131 & & 0.133 & & 0.146 & & 0.144 \\
\hline & & $(0.337)$ & & $(0.340)$ & & $(0.353)$ & & $(0.351)$ \\
\hline \multirow{2}{*}{ Immigrated in $1981-1985$} & & 0.185 & & 0.177 & & 0.162 & & 0.214 \\
\hline & & $(0.388)$ & & $(0.382)$ & & $(0.369)$ & & $(0.410)$ \\
\hline \multirow{2}{*}{ Immigrated in $1986-1990$} & & 0.158 & & 0.163 & & 0.129 & & 0.153 \\
\hline & & $(0.365)$ & & $(0.370)$ & & $(0.336)$ & & $(0.360)$ \\
\hline \multirow[t]{2}{*}{ Immigrated in $1991-1995$} & & 0.122 & & 0.121 & & 0.118 & & 0.112 \\
\hline & & $(0.328)$ & & $(0.326)$ & & $(0.323)$ & & $(0.316)$ \\
\hline \multirow[t]{2}{*}{ Immigrated in $1996-2000$} & & 0.099 & & 0.111 & & 0.078 & & 0.114 \\
\hline & & $(0.299)$ & & $(0.314)$ & & $(0.269)$ & & $(0.318)$ \\
\hline \multirow[t]{2}{*}{ Immigrated in $2001-2005$} & & 0.086 & & 0.103 & & 0.049 & & 0.092 \\
\hline & & $(0.280)$ & & $(0.304)$ & & $(0.215)$ & & $(0.288)$ \\
\hline \multirow[t]{2}{*}{ Immigrated in $2006-2014$} & & 0.062 & & 0.051 & & 0.041 & & 0.072 \\
\hline & & $(0.242)$ & & $(0.219)$ & & $(0.198)$ & & $(0.259)$ \\
\hline \multirow[t]{2}{*}{$0-1$ Years since Arrival } & & 0.028 & & 0.023 & & 0.038 & & 0.015 \\
\hline & & $(0.166)$ & & $(0.151)$ & & $(0.190)$ & & $(0.122)$ \\
\hline \multirow[t]{2}{*}{ 1-4 Years since Arrival } & & 0.169 & & 0.151 & & 0.156 & & 0.152 \\
\hline & & $(0.375)$ & & $(0.358)$ & & $(0.363)$ & & $(0.359)$ \\
\hline \multirow[t]{2}{*}{ 5-9 Years since Arrival } & & 0.244 & & 0.257 & & 0.182 & & 0.276 \\
\hline & & $(0.430)$ & & $(0.437)$ & & $(0.386)$ & & $(0.447)$ \\
\hline \multirow[t]{2}{*}{ 10-14 Years since Arrival } & & 0.211 & & 0.229 & & 0.149 & & 0.247 \\
\hline & & $(0.408)$ & & $(0.420)$ & & $(0.356)$ & & $(0.431)$ \\
\hline \multirow[t]{2}{*}{$15+$ Years since Arrival } & & 0.347 & & 0.341 & & 0.475 & & 0.311 \\
\hline & & $(0.476)$ & & $(0.474)$ & & $(0.499)$ & & $(0.463)$ \\
\hline \multirow[t]{2}{*}{ Age } & 42.794 & 43.078 & 39.671 & 42.355 & 43.062 & 46.389 & 42.849 & 42.748 \\
\hline & $(11.043)$ & $(11.450)$ & $(10.702)$ & $(11.523)$ & $(11.014)$ & $(11.222)$ & $(11.121)$ & $(10.785)$ \\
\hline \multirow[t]{2}{*}{ Married } & 0.647 & 0.704 & 0.578 & 0.699 & 0.681 & 0.720 & 0.485 & 0.590 \\
\hline & $(0.478)$ & $(0.457)$ & $(0.494)$ & $(0.459)$ & $(0.466)$ & $(0.449)$ & $(0.500)$ & $(0.492)$ \\
\hline Years of Education & 13.218 & 11.817 & 12.388 & 9.587 & 13.427 & 14.026 & 12.294 & 13.136 \\
\hline & $(2.676)$ & $(4.565)$ & $(2.703)$ & $(4.353)$ & $(2.644)$ & $(3.454)$ & $(2.558)$ & $(3.219)$ \\
\hline Working/Employed & 0.832 & 0.830 & 0.816 & 0.831 & 0.852 & 0.824 & 0.725 & 0.832 \\
\hline & $(0.374)$ & $(0.376)$ & $(0.388)$ & $(0.374)$ & $(0.355)$ & $(0.380)$ & $(0.446)$ & $(0.374)$ \\
\hline Sample size & 306,086 & 36,205 & 18,680 & 18,480 & 242,473 & 7,006 & 38,427 & 2,774 \\
\hline
\end{tabular}

Notes: NHIS data from 1989-2014 for individuals aged 25-64. All the samples contain individuals for whom information on all observables are not missing. Standard deviations are in parentheses. 
Table 2: Summary Statistics for Women, by Nativity and Ethnic Origin

\begin{tabular}{|c|c|c|c|c|c|c|c|c|}
\hline \multirow[b]{2}{*}{ Variable } & \multicolumn{2}{|c|}{ All Origins } & \multicolumn{2}{|c|}{ Hispanic } & \multicolumn{2}{|c|}{ White } & \multicolumn{2}{|c|}{ Black } \\
\hline & Native & Immigrant & Native & Immigrant & Native & Immigrant & Native & Immigrant \\
\hline \multirow[t]{2}{*}{ BMI } & 26.010 & 25.533 & 27.431 & 26.718 & 25.353 & 24.749 & 28.404 & 27.191 \\
\hline & $(5.776)$ & $(4.927)$ & $(5.920)$ & $(4.922)$ & $(5.496)$ & $(4.742)$ & $(6.194)$ & $(4.962)$ \\
\hline \multirow{2}{*}{ Overweight (BMI 25+) } & 0.476 & 0.473 & 0.592 & 0.582 & 0.423 & 0.397 & 0.670 & 0.635 \\
\hline & $(0.499)$ & $(0.499)$ & $(0.491)$ & $(0.493)$ & $(0.494)$ & $(0.489)$ & $(0.470)$ & $(0.481)$ \\
\hline \multirow{2}{*}{ Obese (BMI 30+) } & 0.215 & 0.171 & 0.293 & 0.227 & 0.179 & 0.131 & 0.347 & 0.250 \\
\hline & $(0.411)$ & $(0.376)$ & $(0.455)$ & $(0.419)$ & $(0.384)$ & $(0.337)$ & $(0.476)$ & $(0.433)$ \\
\hline \multirow{2}{*}{ Immigrated in $1960-1970$} & & 0.170 & & 0.146 & & 0.331 & & 0.117 \\
\hline & & $(0.376)$ & & $(0.353)$ & & $(0.470)$ & & $(0.321)$ \\
\hline \multirow{2}{*}{ Immigrated in $1971-1980$} & & 0.132 & & 0.141 & & 0.135 & & 0.137 \\
\hline & & $(0.339)$ & & $(0.348)$ & & $(0.342)$ & & $(0.344)$ \\
\hline \multirow{2}{*}{ Immigrated in $1981-1985$} & & 0.172 & & 0.165 & & 0.141 & & 0.200 \\
\hline & & $(0.377)$ & & $(0.372)$ & & $(0.348)$ & & $(0.400)$ \\
\hline \multirow{2}{*}{ Immigrated in $1986-1990$} & & 0.151 & & 0.152 & & 0.119 & & 0.164 \\
\hline & & $(0.358)$ & & $(0.359)$ & & $(0.324)$ & & $(0.371)$ \\
\hline \multirow{2}{*}{ Immigrated in $1991-1995$} & & 0.133 & & 0.139 & & 0.110 & & 0.119 \\
\hline & & $(0.339)$ & & $(0.346)$ & & $(0.313)$ & & $(0.323)$ \\
\hline \multirow[t]{2}{*}{ Immigrated in $1996-2000$} & & 0.098 & & 0.112 & & 0.074 & & 0.099 \\
\hline & & $(0.297)$ & & $(0.315)$ & & $(0.262)$ & & $(0.299)$ \\
\hline \multirow[t]{2}{*}{ Immigrated in $2001-2005$} & & 0.087 & & 0.099 & & 0.051 & & 0.094 \\
\hline & & $(0.281)$ & & $(0.298)$ & & $(0.221)$ & & $(0.292)$ \\
\hline \multirow[t]{2}{*}{ Immigrated in $2006-2014$} & & 0.058 & & 0.046 & & 0.038 & & 0.070 \\
\hline & & $(0.233)$ & & $(0.210)$ & & $(0.191)$ & & $(0.255)$ \\
\hline \multirow[t]{2}{*}{ 0-1 Years since Arrival } & & 0.025 & & 0.019 & & 0.029 & & 0.022 \\
\hline & & $(0.157)$ & & $(0.137)$ & & $(0.168)$ & & $(0.145)$ \\
\hline \multirow[t]{2}{*}{ 1-4 Years since Arrival } & & 0.163 & & 0.143 & & 0.150 & & 0.155 \\
\hline & & $(0.370)$ & & $(0.350)$ & & $(0.357)$ & & $(0.362)$ \\
\hline \multirow[t]{2}{*}{ 5-9 Years since Arrival } & & 0.239 & & 0.256 & & 0.167 & & 0.270 \\
\hline & & $(0.427)$ & & $(0.436)$ & & $(0.373)$ & & $(0.444)$ \\
\hline \multirow[t]{2}{*}{ 10-14 Years since Arrival } & & 0.204 & & 0.223 & & 0.131 & & 0.232 \\
\hline & & $(0.403)$ & & $(0.416)$ & & $(0.338)$ & & $(0.422)$ \\
\hline \multirow[t]{2}{*}{$15+$ Years since Arrival } & & 0.368 & & 0.359 & & 0.523 & & 0.321 \\
\hline & & $(0.482)$ & & $(0.480)$ & & $(0.500)$ & & $(0.467)$ \\
\hline \multirow[t]{2}{*}{ Age } & 42.616 & 43.718 & 39.434 & 42.969 & 43.057 & 47.335 & 42.088 & 43.269 \\
\hline & $(11.132)$ & $(11.519)$ & $(10.747)$ & $(11.474)$ & $(11.125)$ & $(11.365)$ & $(11.086)$ & $(10.851)$ \\
\hline \multirow[t]{2}{*}{ Married } & 0.598 & 0.639 & 0.521 & 0.598 & 0.665 & 0.716 & 0.334 & 0.465 \\
\hline & $(0.490)$ & $(0.480)$ & $(0.500)$ & $(0.490)$ & $(0.472)$ & $(0.451)$ & $(0.472)$ & $(0.499)$ \\
\hline Years of Education & 13.120 & 11.360 & 12.208 & 9.629 & 13.337 & 13.280 & 12.506 & 12.239 \\
\hline & $(2.501)$ & $(4.381)$ & $(2.738)$ & $(4.294)$ & $(2.450)$ & $(3.327)$ & $(2.406)$ & $(3.263)$ \\
\hline Working/Employed & 0.691 & 0.554 & 0.657 & 0.495 & 0.703 & 0.588 & 0.651 & 0.726 \\
\hline & $(0.462)$ & $(0.497)$ & $(0.475)$ & $(0.500)$ & $(0.457)$ & $(0.492)$ & $(0.477)$ & $(0.446)$ \\
\hline Sample size & 345,657 & 41,845 & 23,494 & 21,442 & 258,012 & 7,978 & 56,949 & 3,154 \\
\hline
\end{tabular}

Notes: NHIS data from 1989-2014 for individuals aged 25-64. All the samples contain individuals for whom information on all observables are not missing. Standard deviations are in parentheses. 
Table 3: Linear probability model allowing for cohort effects in both obesity levels and obesity growth rates

\begin{tabular}{|c|c|c|c|c|c|c|}
\hline \multirow[b]{3}{*}{ Variable } & (1) & (2) & (3) & \multirow{3}{*}{$\begin{array}{c}(4) \\
\text { Hispanic } \\
\text { Overall }\end{array}$} & \multirow{3}{*}{$\begin{array}{c}(5) \\
\text { White } \\
\text { Overall }\end{array}$} & \multirow{3}{*}{$\begin{array}{c}(6) \\
\text { Black } \\
\text { Overall }\end{array}$} \\
\hline & \multicolumn{3}{|c|}{ All Origins } & & & \\
\hline & Overall & Male & Female & & & \\
\hline \multicolumn{7}{|l|}{ Cohort Effects: } \\
\hline $1985-1990$ arrivals & $\begin{array}{c}-0.119^{* * *} \\
(0.004)\end{array}$ & $\begin{array}{c}-0.144^{* * *} \\
(0.006)\end{array}$ & $\begin{array}{c}-0.095^{* * *} \\
(0.005)\end{array}$ & $\begin{array}{c}-0.179^{* * *} \\
(0.005)\end{array}$ & $\begin{array}{c}-0.093^{* * *} \\
(0.012)\end{array}$ & $\begin{array}{c}-0.198^{* * *} \\
(0.023)\end{array}$ \\
\hline $1990-1995$ arrivals & $\begin{array}{c}-0.096^{* * *} \\
(0.004)\end{array}$ & $\begin{array}{c}-0.107^{* * *} \\
(0.006)\end{array}$ & $\begin{array}{c}-0.087^{* * *} \\
(0.004)\end{array}$ & $\begin{array}{c}-0.148^{* * *} \\
(0.005)\end{array}$ & $\begin{array}{c}-0.051^{* * *} \\
(0.011)\end{array}$ & $\begin{array}{c}-0.124^{* * *} \\
(0.019)\end{array}$ \\
\hline $1995-2000$ arrivals & $\begin{array}{c}-0.091 * * * \\
(0.004)\end{array}$ & $\begin{array}{c}-0.110^{* * *} \\
(0.006)\end{array}$ & $\begin{array}{c}-0.072^{* * *} \\
(0.004)\end{array}$ & $\begin{array}{c}-0.160 * * * \\
(0.005)\end{array}$ & $\begin{array}{c}-0.060 * * * \\
(0.011)\end{array}$ & $\begin{array}{c}-0.161^{* * *} \\
(0.019)\end{array}$ \\
\hline $2000-2005$ arrivals & $\begin{array}{c}-0.084^{* * *} \\
(0.005)\end{array}$ & $\begin{array}{c}-0.107^{* * *} \\
(0.007)\end{array}$ & $\begin{array}{c}-0.060^{* * *} \\
(0.004)\end{array}$ & $\begin{array}{c}-0.146^{* * *} \\
(0.005)\end{array}$ & $\begin{array}{c}-0.068^{* * *} \\
(0.012)\end{array}$ & $\begin{array}{c}-0.167^{* * *} \\
(0.022)\end{array}$ \\
\hline 2005-2014 arrivals & $\begin{array}{c}-0.089^{* * *} \\
(0.004)\end{array}$ & $\begin{array}{c}-0.110^{* * *} \\
(0.006)\end{array}$ & $\begin{array}{c}-0.067^{* * *} \\
(0.004)\end{array}$ & $\begin{array}{c}-0.124^{* * *} \\
(0.005)\end{array}$ & $\begin{array}{c}-0.066^{* * *} \\
(0.011)\end{array}$ & $\begin{array}{c}-0.148^{* * *} \\
(0.021)\end{array}$ \\
\hline \multicolumn{7}{|c|}{$\begin{array}{l}\text { Relative obesity growth } \\
\text { in first } 10 \text { years: }\end{array}$} \\
\hline $1960-1980$ arrivals & $\begin{array}{c}0.046^{* * *} \\
(0.006)\end{array}$ & $\begin{array}{c}0.061 * * * \\
(0.007)\end{array}$ & $\begin{array}{c}0.031^{* * *} \\
(0.008)\end{array}$ & $\begin{array}{c}0.056^{* * *} \\
(0.008)\end{array}$ & $\begin{array}{l}0.001 \\
(0.017)\end{array}$ & $\begin{array}{l}-0.002 \\
(0.036)\end{array}$ \\
\hline $1980-1985$ arrivals & $\begin{array}{c}0.061 * * * \\
(0.006)\end{array}$ & $\begin{array}{c}0.080 * * * \\
(0.006)\end{array}$ & $\begin{array}{c}0.043^{* * *} \\
(0.008)\end{array}$ & $\begin{array}{c}0.081 * * * \\
(0.007)\end{array}$ & $\begin{array}{l}0.020 \\
(0.016)\end{array}$ & $\begin{array}{c}0.011 \\
(0.035)\end{array}$ \\
\hline $1985-1990$ arrivals & $\begin{array}{c}0.056^{* * *} \\
(0.005)\end{array}$ & $\begin{array}{c}0.074^{* * *} \\
(0.006)\end{array}$ & $\begin{array}{c}0.039^{* * *} \\
(0.007)\end{array}$ & $\begin{array}{c}0.066^{* * *} \\
(0.007)\end{array}$ & $\begin{array}{c}0.013 \\
(0.015)\end{array}$ & $\begin{array}{c}0.047 \\
(0.033)\end{array}$ \\
\hline $1990-1995$ arrivals & $\begin{array}{c}0.062^{* * *} \\
(0.004)\end{array}$ & $\begin{array}{c}0.063^{* * *} \\
(0.006)\end{array}$ & $\begin{array}{c}0.059^{* * *} \\
(0.005)\end{array}$ & $\begin{array}{c}0.055^{* * *} \\
(0.006)\end{array}$ & $\begin{array}{l}-0.012 \\
(0.013)\end{array}$ & $\begin{array}{c}0.017 \\
(0.027)\end{array}$ \\
\hline $1995-2000$ arrivals & $\begin{array}{c}0.074^{* * *} \\
(0.004)\end{array}$ & $\begin{array}{c}0.101^{* * *} \\
(0.005)\end{array}$ & $\begin{array}{c}0.048^{* * *} \\
(0.005)\end{array}$ & $\begin{array}{c}0.097^{* * *} \\
(0.006)\end{array}$ & $\begin{array}{c}0.003 \\
(0.013)\end{array}$ & $\begin{array}{c}0.081^{* *} \\
(0.027)\end{array}$ \\
\hline 2000-2014 arrivals & $\begin{array}{c}0.087^{* * *} \\
(0.005)\end{array}$ & $\begin{array}{c}0.105^{* * *} \\
(0.007)\end{array}$ & $\begin{array}{c}0.066^{* * *} \\
(0.005)\end{array}$ & $\begin{array}{c}0.105^{* * *} \\
(0.006)\end{array}$ & $\begin{array}{c}0.037^{* *} \\
(0.016)\end{array}$ & $\begin{array}{c}0.070^{* *} \\
(0.030)\end{array}$ \\
\hline Observations & 729,793 & 342,291 & 387,502 & 82,096 & 515,469 & 101,304 \\
\hline
\end{tabular}

Notes: Standard errors are reported in parentheses and are clustered at the cohort level. All regressions include the individual's age (introduced as a third-order polynomial) fully interacted with a variable indicating if the person is foreign-or native-born. The calculation of the relative obesity growth in the first 10 years assumes that the immigrant arrives in the United States at age 25.

* Significant at $10 \%$; ${ }^{* *}$ significant at $5 \%$; $* *$ significant at $1 \%$. 
Table 4: Probit model for cohort effects in both obesity levels and obesity growth rates

\begin{tabular}{|c|c|c|c|c|c|c|}
\hline \multirow[b]{3}{*}{ Variable } & (1) & $(2)$ & (3) & \multirow{3}{*}{$\begin{array}{c}(4) \\
\text { Hispanic } \\
\text { Overall }\end{array}$} & \multirow{3}{*}{$\begin{array}{c}\text { (5) } \\
\text { White } \\
\text { Overall }\end{array}$} & \multirow{3}{*}{$\begin{array}{c}(6) \\
\text { Black } \\
\text { Overall }\end{array}$} \\
\hline & \multicolumn{3}{|c|}{ All Origins } & & & \\
\hline & Overall & Male & Female & & & \\
\hline \multicolumn{7}{|l|}{ Cohort Effects: } \\
\hline \multirow[t]{2}{*}{$1985-1990$ arrivals } & $-0.165 * * *$ & $-0.215^{* * *}$ & $-0.125^{* * *}$ & $-0.222 * * *$ & $-0.151 * * *$ & $-0.295^{* * *}$ \\
\hline & $(0.006)$ & $(0.010)$ & $(0.006)$ & $(0.006)$ & $(0.022)$ & $(0.038)$ \\
\hline \multirow[t]{2}{*}{ 1990-1995 arrivals } & $-0.141 * * *$ & $-0.167 * * *$ & $-0.122 * * *$ & $-0.191 * * *$ & $-0.093^{* * *}$ & $-0.192 * * *$ \\
\hline & $(0.005)$ & $(0.010)$ & $(0.005)$ & $(0.005)$ & $(0.020)$ & $(0.032)$ \\
\hline \multirow[t]{2}{*}{$1995-2000$ arrivals } & $-0.130 * * *$ & $-0.163^{* * *}$ & $-0.101 * * *$ & $-0.204 * * *$ & $-0.105^{* * *}$ & $-0.243^{* * *}$ \\
\hline & $(0.005)$ & $(0.009)$ & $(0.005)$ & $(0.005)$ & $(0.020)$ & $(0.033)$ \\
\hline \multirow[t]{2}{*}{$2000-2005$ arrivals } & $-0.118^{* * *}$ & $-0.160 * * *$ & $-0.082 * * *$ & $-0.183^{* * *}$ & $-0.115^{* * *}$ & $-0.252 * * *$ \\
\hline & $(0.010)$ & $(0.016)$ & $(0.005)$ & $(0.005)$ & $(0.020)$ & $(0.037)$ \\
\hline \multirow[t]{2}{*}{ 2005-2014 arrivals } & $-0.124^{* * *}$ & $-0.164^{* * *}$ & $-0.090 * * *$ & $-0.155^{* * *}$ & $-0.111 * * *$ & $-0.224^{* * *}$ \\
\hline & $(0.007)$ & $(0.013)$ & $(0.005)$ & $(0.005)$ & $(0.019)$ & $(0.035)$ \\
\hline \multirow{2}{*}{\multicolumn{7}{|c|}{$\begin{array}{l}\text { Relative obesity growth } \\
\text { in first } 10 \text { years: }\end{array}$}} \\
\hline & & & & & & \\
\hline \multirow[t]{2}{*}{$1960-1980$ arrivals } & $0.069^{* * *}$ & $0.100 * * *$ & $0.045^{* * *}$ & $0.085 * * *$ & 0.023 & 0.048 \\
\hline & $(0.008)$ & $(0.011)$ & $(0.010)$ & $(0.009)$ & $(0.028)$ & $(0.052)$ \\
\hline \multirow[t]{2}{*}{$1980-1985$ arrivals } & $0.085^{* * *}$ & $0.121^{* * *}$ & $0.057^{* * *}$ & $0.111^{* * *}$ & 0.040 & 0.059 \\
\hline & $(0.008)$ & $(0.011)$ & $(0.010)$ & $(0.009)$ & $(0.027)$ & $(0.051)$ \\
\hline \multirow[t]{2}{*}{$1985-1990$ arrivals } & $0.080^{* * *}$ & $0.117^{* * *}$ & $0.052^{* * *}$ & $0.097^{* * *}$ & 0.034 & $0.101^{* *}$ \\
\hline & $(0.007)$ & $(0.010)$ & $(0.009)$ & $(0.008)$ & $(0.026)$ & $(0.048)$ \\
\hline \multirow[t]{2}{*}{$1990-1995$ arrivals } & $0.100^{* * *}$ & $0.117^{* * *}$ & $0.089^{* * *}$ & $0.095 * * *$ & 0.008 & 0.065 \\
\hline & $(0.006)$ & $(0.010)$ & $(0.006)$ & $(0.007)$ & $(0.022)$ & $(0.041)$ \\
\hline \multirow[t]{2}{*}{$1995-2000$ arrivals } & $0.109^{* * *}$ & $0.154 * * *$ & $0.072^{* * *}$ & $0.140^{* * *}$ & 0.028 & $0.145^{* * *}$ \\
\hline & $(0.006)$ & $(0.009)$ & $(0.007)$ & $(0.007)$ & $(0.022)$ & $(0.041)$ \\
\hline \multirow[t]{2}{*}{$2000-2014$ arrivals } & $0.119^{* * *}$ & $0.159 * * *$ & $0.085^{* * *}$ & $0.141 * * *$ & $0.070^{* * *}$ & $0.136^{* * *}$ \\
\hline & $(0.011)$ & $(0.017)$ & $(0.007)$ & $(0.007)$ & $(0.024)$ & $(0.046)$ \\
\hline Observations & 729,793 & 342,291 & 387,502 & 82,096 & 515,469 & 101,304 \\
\hline
\end{tabular}

Notes: Probit estimation: average marginal effects reported. Standard errors are reported in parentheses and are clustered at the cohort level. All regressions include the individual's age (introduced as a third-order polynomial) fully interacted with a variable indicating if the person is foreign-or native-born. The calculation of the relative obesity growth in the first 10 years assumes that the immigrant arrives in the United States at age 25 .

* Significant at $10 \% ; * *$ significant at $5 \% ; * * *$ significant at $1 \%$. 